\title{
Effects of soybean meal incorporated diet on enzyme producing autochthonous gut bacteria in fingerlings of Labeo rohita (Hamilton)
}

\author{
Pinki Ghosh ${ }^{1}$, Suhas K. Dan ${ }^{1}$, Goutam Banerjee ${ }^{1}$, Sandip Majumder ${ }^{2 *}$, \\ Ankita Nandi ${ }^{1}$, Kousik Roy ${ }^{3}$, Arun K. Ray ${ }^{1}$ \\ ${ }^{1}$ Fisheries Laboratory, Department of Zoology, Visva-Bharati University, Santiniketan, India \\ ${ }^{2}$ Fish Biology and Aquatic Ecology Laboratory, Department of Zoology, Visva-Bharati University, Santiniketan, India \\ ${ }^{3}$ Fish Biology and Toxicology Laboratory, Department of Zoology, Visva-Bharati University, Santiniketan, India \\ *Corresponding author e-mail: sandip198518@gmail.com
}

Available online at: www.isroset.org

Accepted: 25/Aug/2018, Online: 30/Aug/ 2018

\begin{abstract}
Gut microbiota have important role in the digestive process of fish. Soybean meal based diet effects on gut microbiota of Labeo rohita by altering enzymatic activities like amylase, protease and cellulase. Two diets were prepared, one using fish meal and the other using soybean meal as the major protein source. The feeding trial was conducted in $90 \mathrm{~L}$ circular flow-through fibre-glass tanks for 90 days under laboratory condition. After ninety days of feeding trial fish weight gain percentage, SGR FCR, PER was better with soybean meal diet in comparison to the fish meal diet. Amylase, cellulase and protease producing aerobic bacterial count were increased in both the proximal intestine (PI) and distal intestine (DI). The isolated strains from the PI and DI of the test fish were screened by qualitative enzyme test. The specific amylase, cellulase and protease activity before and after feeding trial were recorded. A distinct change in the quantitative enzyme activities in the bacterial strains were noticed after feeding with soybean meal diets which indicated that soybean meal can influence the autochthonous enzyme-producing microbial community in the GI tract of fish.
\end{abstract}

Keywards: Gut bacteria, Soybean meal, Enzyme activity, Labeo rohita, Growth

\section{INTRODUCTION}

As the aquaculture industry grows, the need for specialized feeds designed for particular production situations is increasing. To date, nutritionists and feed manufacturers have concentrated their efforts on determining which of the wide variety of feedstuffs available to the feed industry may be used to produce lower cost aquaculture feeds. Consequently, a great part of current research in fish nutrition and feeding is devoted to the development of artificial diets for larvae of the more common cultivated finfish. Replacement of fish meal with cheaper ingredients of either vegetable or animal origin in fish feed is necessary because of rising cost and uncertain availability of fish meal [1]. The scarcity of good quality fishmeal and escalating prices thereof have generated renewed interest to use less expensive plant protein sources to partially replace fishmeal is a major research priority [2]. Among all protein rich plant feed stuffs, soybean meal protein has one of the best amino acid profiles to meet the high protein requirement and provides an added advantage in feed formulations because of its essential amino acid contents. The amino acid profile of soya protein is generally superior to those of the other plant proteins [3].

It has been proved in different studies that fish harbor their own resident microbial flora which may help the host in digestion by secreting a variety of enzymes [4]. The fish gut microbiota may help the host by producing a range of digestive enzymes like amylase, protease and lipase and also may help in degradation of cellulose by producing cellulase and other anti-nutrients like phytic acid, tannin etc. And it is also reported that different feeding regimes alter the enzymatic activity of those isolates [5].

Even though fish microbiologists have gained some knowledge about adherence of bacteria in the GI tract of fish during the last two decades, it is a long way to go compared to the information available from non-aquaculture studies. However, to the author's knowledge, there is no information available regarding soybean meal (SBM) based dietary effect on gut microbiota of Labeo rohita. Therefore, considering the importance of Indian major carps and the role of enzyme producing bacteria in 
commercial aquaculture, the present study is focused on SBM based dietary effect on gut microbiota of L. rohita and enzymatic activities like amylase, protease and cellulase.

\section{MATERIALS AND METHODS}

\section{Experimental diets}

Two diets were prepared using fish meal or SBM meal as the major protein source (Table 1). The sun-dried soybean were finely ground and passed through a fine meshed sieve to ensure homogeneity. The SBM contained $48.38 \%$ crude protein and $4.3 \%$ crude fibre on dry matter basis whereas, fish meal contained $58.5 \%$ crude protein and $3.9 \%$ crude fibre, respectively. Diets were made isonitrogenous (35\% crude protein) and isolipidic (8.5\%). Dry feed ingredients were mixed and the diets were prepared from using $0.5 \%$ carboxymethylcellulose as a binder. The pellets were sun dried for a few days and crumbled prior to feeding.

Table 1: Composition ( $\mathrm{g} / \mathrm{kg}$ dry weight) of the diets

\begin{tabular}{|c|c|c|}
\hline \multirow{2}{*}{ Ingredients } & \multicolumn{2}{|c|}{$\mathbf{g ~ k g}^{-\mathbf{1}}$ diet } \\
\cline { 2 - 3 } & FM diet & SBM diet \\
\hline Fishmeal & 450 & 240 \\
\hline Soybean meal (SBM) & - & 400 \\
\hline Mustard oil cake & 240 & 180 \\
\hline Rice barn & 290 & 160 \\
\hline Soybean oil & - & 10 \\
\hline Cod liver oil & 10 & - \\
\hline Vitamin premix & & 10 \\
\hline
\end{tabular}

${ }^{\mathrm{a}}$ Vitamin and mineral mixture (Vitaminetes forte, Roche Products India Private Limited, Mumbai, India)

\section{Experimental design}

The feeding trial was conducted in flow-through 90L circular fibre-glass tanks for 90 days under laboratory condition. Each tank was supplied with unchlorinated water from a deep tube well with continuous aeration. L. rohita, fingerlings were obtained from a local fish farm and acclimatized for 15 days and fed with a mixture of rice bran and mustard oil cake. The fingerlings (Avg. initial weight $9.48 \pm 0.12 \mathrm{~g}$ ) were randomly distributed in the fibre-glass tanks at a stocking density of 15 fish per tank with three replicates for each dietary treatment. The fish were fed once daily at $10.00 \mathrm{~h}$ at a feeding rate of $3 \%$ of total body weight per day. The quantity of feed given was readjusted every 15 th day after weighing the fish. Weight gain (\%), specific growth rate (SGR, \%/day), feed conversion ratio (FCR) and protein efficiency ratio (PER) were calculated using standard methods.

\section{Microbial culture}

Isolation of bacteria was done from the intestine of $L$. rohita fingerlings both prior to and at the termination of the feeding trial. In each case, the test fish were starved for $36 \mathrm{~h}$ prior to sacrifice to clean the intestine. The fish were carefully placed aseptically within laminar airflow on ice slabs and their intestines were removed and cleaned with sterile physiological saline solution. The intestine was divided into proximal (PI) and distal intestine (DI) as described by [6]. The contents from the two regions of the gut were squeezed out. Thereafter, both the regions of the gut were cleaned, slit opened by a longitudinal incision, transferred to sterile Petri dishes, and thoroughly flushed with sterilized chilled $0.9 \%$ saline in order to remove nonadherent or allochthonous bacteria chilled $0.9 \%$ saline in order to remove non-adherent or allochthonous bacteria. The two regions of the alimentary tract were separately homogenized with 10 parts of chilled $0.9 \%$ sodium chloride solution [7]. Bacteria associated with gut were quantified as log total viable count (TVC) per g intestinal tissue using three different types of agar. The total numbers of resident or autochthonous aerobic bacteria were estimated with plate count agar (Tryptic soy agar, TSA). For isolation and enumeration of protease-, amylase- and cellulase-producing bacteria, the diluted gut homogenates were spread onto the surface of peptone-gelatin agar, starch-agar and carboxymethylcellulose (CMC)-agar media plates, respectively.

Enzyme-producing capacity of isolated bacterial strains Screening of isolates by qualitative enzyme production 
The isolated strains from the PI and DI of the test fish were screened for the production of extracellular protease, amylase and cellulase on agar plates of the selective media, namely, peptone-gelatin agar, starch-agar, and (CMC) - agar, respectively [8]. Qualitative extracellular enzyme activities were assessed based on the measurement of a clear zone (halo) around the colonies as follows: + (low, 5-14 mm halo diameter), ++ (moderate, 15-24 mm halo diameter), and +++ (high, 25-35 $\mathrm{mm}$ halo diameter).

\section{Quantitative enzyme assay}

After primary qualitative screening, the selected strains were cultured in selective liquid medium for quantitative enzyme assay. The strains were cultured in $4 \%$ tryptone soya broth for $24 \mathrm{~h}$ at $37 \pm 1{ }^{\circ} \mathrm{C}$ and used as the inoculum. Liquid production medium of $20 \mathrm{ml}$ was inoculated with $0.5 \mathrm{ml}$ of inoculum obtained from the seed culture and incubated for $48-96 \mathrm{~h}$ at the same temperature. The contents of the culture flasks were centrifuged $\left(9,000 \times g, 10 \mathrm{~m}, 4^{0} \mathrm{C}\right)$, and the cell-free supernatant was used for enzyme assay. The protein content of the crude enzyme extract was estimated according to [9]. The quantitative assay of amylase, cellulase and protease was performed using the methods described by [10], [11] and [12], respectively. Specific enzyme activity was expressed as a unit (U)/mg protein.

\section{RESULTS}

After ninety days of feeding trial the growth performance and feed utilization of $L$. rohita fingerlings in terms of percentage weight gain, SGR, FCR and PER fed with fish meal and SBM diet were observed, presented in Table 2. The performance of fish weight gain (\%), SGR FCR, PER was better with soybean meal diet in comparison to the fish meal diet.

Table 2: Growth and feed utilization efficiencies in C. mrigala fingerlings fed experimental diets for 90 days.

\begin{tabular}{|c|c|c|}
\hline Mean Values & Fish meal diet & SBM diet \\
\hline Initial weight $(\mathrm{g})$ & $9.48 \pm 0.12$ & $9.48 \pm 0.12$ \\
\hline Final weight $(\mathrm{g})$ & $19.18 \pm 0.25$ & $22.24 \pm 0.56$ \\
\hline Weight gain $(\%)$ & $102.32 \pm 0.16$ & $134.59 \pm 0.21$ \\
\hline SGR (\%/ day) & $0.987 \pm 0.7$ & $1.321 \pm 0.8$ \\
\hline FCR & $3.02 \pm 0.05$ & $2.97 \pm 0.07$ \\
\hline PER & $1.42 \pm 0.06$ & $1.09 \pm 0.08$ \\
\hline
\end{tabular}

Before initiation of the feeding trial and after ninety days of feeding, bacteria associated with gut were quantified as log total viable count (TVC) per g intestinal tissue using three different types of agar.The bacterial counts in TSA, starch agar, CMC agar and gelatin agar plates are presented in Table 3 and Table 4 respectively. Before feeding trial total log viable count was highest in hindgut on TSA plate and amylase plate except protease and cellulase. After feeding the aerobic bacterial count was highest in the proximal intestine (PI) (log viable count $=7.22 \mathrm{~g}^{-1}$ intestinal tissue) of $L$. rohita fed with SBM based diet while the amylase-producing bacterial count was highest in the distal intestine of $L$. rohita (log $=5.24 \mathrm{~g}^{-1}$ intestinal tissue) before feeding trial and the cellulase producing bacterial count was highest in the proximal intestine of $L$. rohita $\left(\log =4.43 \mathrm{~g}^{-1}\right.$ intestinal tissue) before feeding trial but the protease producing bacterial count was highest in the distal intestine of $L$. rohita ( $\log =4.45 \mathrm{~g}^{-1}$ intestinal tissue) fed with SBM based diet after 90 days of feeding trial.

Table 3: Log total viable counts (TVC)) of aerobic amylase-, cellulase- and protease -producing bacteria per g intestinal tissue in the GI tract of L. rohita before feeding trial.

\begin{tabular}{|c|c|c|c|c|}
\hline Gut Region & Total bacterial count (TSA) & $\begin{array}{c}\text { Amylase producing } \\
\text { bacteria }\end{array}$ & $\begin{array}{c}\text { Cellulase producing } \\
\text { bacteria }\end{array}$ & $\begin{array}{c}\text { Protease producing } \\
\text { bacteria }\end{array}$ \\
\hline Proximal intestine (PI) & 5.71 & 4.55 & 4.43 & 4.25 \\
\hline Distal intestine (DI) & 6.68 & 5.24 & 3.31 & 4.22 \\
\hline
\end{tabular}

Table 4: Log total viable counts (TVC)) of aerobic amylase-, cellulase- and protease -producing bacteria per g intestinal tissue in the GI tract of L. rohita after feeding trial.

\begin{tabular}{|c|c|c|c|c|c|}
\hline Gut Region & Diets & $\begin{array}{c}\text { Total bacterial } \\
\text { count (TSA) }\end{array}$ & $\begin{array}{c}\text { Amylase producing } \\
\text { bacteria }\end{array}$ & $\begin{array}{c}\text { Cellulase producing } \\
\text { bacteria }\end{array}$ & $\begin{array}{c}\text { Protease producing } \\
\text { bacteria }\end{array}$ \\
\hline \multirow{2}{*}{$\begin{array}{c}\text { Proximal } \\
\text { intestine (PI) }\end{array}$} & Fish meal & 5.59 & 3.91 & 3.60 & 3.67 \\
\cline { 2 - 6 } & SBM & 7.22 & 5.11 & 4.16 & 4.19 \\
\hline $\begin{array}{c}\text { Distal intestine } \\
\text { (DI) }\end{array}$ & Fish meal & 5.29 & 3.54 & 3.85 & 4.31 \\
\cline { 2 - 6 } & SBM & 5.65 & 4.92 & 3.78 & 4.45 \\
\hline
\end{tabular}


After feeding trial with fishmeal and SBM diet isolation of bacterial isolates by pure culture, qualitative amylase, cellulase and protease assay were carried out with a total of one hundred seventeen bacterial isolates and isolated strains were screened on the basis of specific amylase cellulase and protease activities. Many of the bacterial isolates did not produce any visible halo or transparent zone of starch, cellulose or tyrosine hydrolysis in the starch, CMC and gelatin plates, respectively after addition of the colour reagent, whereas some isolates produced clear zones of very shorter radius. These bacterial strains were rejected and only the strains which produced good halo were selected (Table 5). Based on the results of the qualitative amylase, cellulase and protease assay, only forty bacterial isolates; twenty from fish meal fed fish gut (ten each from proximal intestine and distal intestine) and twenty from SBM fed fish gut (ten each from PI and DI) were selected for further study. In qualitative assay strains CSF4, CSH5 from fish meal fed fish and LRF3, LRH2 from SBM fed fish showed highest clear zone where as LRF2 and LRH3 strains from SBM fed fish exhibited highest clear zone on CMC agar plate. In case of protease activity strains CSF8 from fish meal fed fish and LRF4, LRH1from SBM fed fish showed highest clear zone (Table 6 and Table 7).

Table 5: Selected bacterial strains for further study.

Selected strains (total 40 isolates)

\begin{tabular}{cll}
\hline Fish & \multicolumn{1}{c}{ Proximal intestine } & \multicolumn{1}{c}{ Distal intestine } \\
\hline Fish fed FM & CSF1, CSF2, CSF3, CSF4, CSF5, CSF6, CSF7, & CSH1, CSH2, CSH3, CSH4, CSH5, CSH6, CSH7, \\
based diet & CSF8, CSF9, CSF10 & CSH8, CSH9, CSH10 \\
$\begin{array}{c}\text { Fish fed SBM } \\
\text { based diet }\end{array}$ & LRF1, LRF2, LRF3, LRF4, LRF5, LRF6, LRF7, & LRH1, LRH2, LRH3, LRH4, LRH5, LRH6, LRH7, \\
\hline
\end{tabular}

Table 6: Qualitative enzyme assay of isolated strains after commencement of feeding trial with fish meal containing diet.

\begin{tabular}{|c|c|c|c|c|}
\hline \multicolumn{5}{|c|}{ Fish Meal Diet } \\
\hline \multirow{11}{*}{ PI } & Strains & Amylase activity & Cellulase activity & Protease activity \\
\hline & CSF1 & + & + & ++ \\
\hline & CSF2 & + & ++ & + \\
\hline & CSF3 & +++ & ++ & +++ \\
\hline & CSF4 & +++ & ++ & + \\
\hline & CSF5 & +++ & +++ & + \\
\hline & CSF6 & ++ & - & + \\
\hline & CSF7 & +++ & + & ++ \\
\hline & CSF8 & + & + & +++ \\
\hline & CSF9 & + & ++ & ++ \\
\hline & CSF10 & + & + & + \\
\hline \multirow{10}{*}{ DI } & CSH1 & ++ & ++ & + \\
\hline & $\mathrm{CSH} 2$ & + & + & ++ \\
\hline & CSH3 & + & + & ++ \\
\hline & CSH4 & + & +++ & ++ \\
\hline & CSH5 & +++ & ++ & + \\
\hline & CSH6 & + & + & ++ \\
\hline & CSH7 & + & ++ & + \\
\hline & CSH8 & ++ & ++ & + \\
\hline & CSH9 & + & + & ++ \\
\hline & CSH10 & ++ & + & ++ \\
\hline
\end{tabular}


Table 7: Qualitative enzyme assay of isolated strains after commencement of feeding trial with SBM containing diet.

\begin{tabular}{|c|c|c|c|c|}
\hline \multicolumn{5}{|c|}{ SBM Diet } \\
\hline \multirow{11}{*}{ PI } & Strains & Amylase activity & Cellulase activity & Protease activity \\
\hline & LRF1 & - & ++ & +++ \\
\hline & LRF2 & ++ & +++ & ++ \\
\hline & LRF3 & +++ & + & ++ \\
\hline & LRF4 & +++ & ++ & +++ \\
\hline & LRF5 & + & +++ & + \\
\hline & LRF6 & +++ & +++ & ++ \\
\hline & LRF7 & ++ & +++ & ++ \\
\hline & LRF8 & + & ++ & + \\
\hline & LRF9 & + & +++ & ++ \\
\hline & LRF10 & ++ & ++ & ++ \\
\hline \multirow{10}{*}{ DI } & LRH1 & ++ & +++ & +++ \\
\hline & LRH2 & +++ & + & + \\
\hline & LRH3 & +++ & +++ & +++ \\
\hline & LRH4 & +++ & + & ++ \\
\hline & LRH5 & +++ & + & + \\
\hline & LRH6 & ++ & ++ & ++ \\
\hline & LRH7 & ++ & +++ & ++ \\
\hline & LRH8 & +++ & +++ & ++ \\
\hline & LRH9 & + & ++ & + \\
\hline & LRH10 & ++ & +++ & +++ \\
\hline
\end{tabular}

'After feeding trial with the fish meal containing diet, the specific quantitative amylase, cellulase and protease activity were recorded (Table 8). The specific highest amylase activity exhibited by strain CSF5 (89.6 $\pm 1.04 \mathrm{U} / \mathrm{mg}$ protein) and CSH5 $(57.61 \pm 0.73 \mathrm{U} / \mathrm{mg}$ protein) isolated from PI and DI respectively. Specific highest cellulase activity showed by strain CSF5 $(26.63 \pm 0.8 \mathrm{U} / \mathrm{mg}$ protein) and CSH4 $(28.33 \pm 0.71 \mathrm{U} / \mathrm{mg}$ protein) isolated from PI and DI respectively. In case of protease highest activity were exhibited by strain CSF3 $(1.76 \pm 0.12 \mathrm{U} / \mathrm{mg}$ protein) and CSH6 $(0.75 \pm 0.06 \mathrm{U} / \mathrm{mg}$ protein) isolated from PI and DI respectively.

A distinct change in the quantitative enzyme activities in the bacterial strains were noticed after feeding trial with SBM diets (Table 9). Quantitative amylase, cellulase and protease assay was also performed with the selected twenty bacterial isolates isolated from SBM fed fish gut. The strain LRF3 $(211.76 \pm 2.2 \mathrm{U} / \mathrm{mg}$ protein) and LRH2 $(200.69 \pm 1.43 \mathrm{U} / \mathrm{mg}$ protein) exhibited highest specific amylase activity isolated from PI and DI respectively. In case of cellulase, highest activity recorded by the strain LRF2 (45.6 $\pm 1.39^{\mathrm{a}} \mathrm{U} / \mathrm{mg}$ protein) and LRH3 $\left(41.39 \pm 1.43^{\mathrm{a}} \mathrm{U} / \mathrm{mg}\right.$ protein) isolated from PI and DI respectively. In case of protease, highest activity showed by the strain LRF4 $\left(2.15 \pm 0.17^{\mathrm{a}} \mathrm{U} / \mathrm{mg}\right.$ protein) and LRH1 $\left(2.58 \pm 0.12^{\mathrm{a}} \mathrm{U} / \mathrm{mg}\right.$ protein $)$ isolated from PI and DI respectively.

Table 8: Quantitative extracellular enzyme activity in the bacterial strains isolated from the GI tract of $L$. rohita fed with Soybean meal, before and after commencement of feeding trial.

\begin{tabular}{|c|c|c|c|c|c|c|c|}
\hline $\begin{array}{c}\text { Proximal } \\
\text { intestine } \\
\text { Strains }\end{array}$ & $\begin{array}{c}\text { Amylase } \\
\text { activity } \\
(\mathrm{U})^{1}\end{array}$ & $\begin{array}{c}\text { Cellulase } \\
\text { activity } \\
(\mathrm{U})^{2}\end{array}$ & $\begin{array}{c}\text { Protease } \\
\text { activity } \\
(\mathrm{U})^{3}\end{array}$ & $\begin{array}{c}\text { Distal } \\
\text { intestine } \\
\text { Strains }\end{array}$ & $\begin{array}{c}\text { Amylase } \\
\text { activity } \\
(\mathrm{U})^{1}\end{array}$ & $\begin{array}{c}\text { Cellulase } \\
\text { activity } \\
(\mathrm{U})^{2}\end{array}$ & $\begin{array}{l}\text { Protease } \\
\text { activity } \\
(\mathrm{U})^{3}\end{array}$ \\
\hline CSF1 & $4.31 \pm 0.46^{\mathrm{l}}$ & $0.27 \pm 0.07^{\mathrm{i}}$ & $0.21 \pm 0.06^{\mathrm{c}}$ & $\mathbf{C S H 1}$ & $18.16 \pm 0.81^{\mathrm{j}}$ & $1.62 \pm 0.14^{\mathrm{h}}$ & $0.33 \pm 0.08^{\mathrm{d}}$ \\
\hline CSF2 & $2.36 \pm 0.5^{\mathrm{I}}$ & $1.29 \pm 0.29^{\mathrm{i}}$ & $0.07 \pm 0.02^{\mathrm{c}}$ & $\mathbf{C S H 2}$ & $6.99 \pm 0.82^{\mathrm{h}}$ & $0.64 \pm 0.16^{\mathrm{h}}$ & $0.36 \pm 0.09^{\mathrm{d}}$ \\
\hline CSF3 & $56.84 \pm 1^{\mathrm{d}}$ & $3.88 \pm 0.4^{\mathrm{h}}$ & $1.76 \pm 0.12^{\mathrm{b}}$ & $\mathbf{C S H 3}$ & $10.23 \pm 0.63^{\mathrm{m}}$ & $0.06 \pm 0.02^{\mathrm{h}}$ & $0.3 \pm 0.08^{\mathrm{d}}$ \\
\hline CSF4 & $34.88 \pm 0.61^{\mathrm{f}}$ & $0.12 \pm 0.05^{\mathrm{i}}$ & $0.53 \pm 0.09^{\mathrm{c}}$ & $\mathbf{C S H 4}$ & $5.48 \pm 0.44^{\mathrm{o}}$ & $28.33 \pm 0.71^{\mathrm{b}}$ & $0.16 \pm 0.05^{\mathrm{d}}$ \\
\hline CSF5 & $89.6 \pm 1.04^{\mathrm{b}}$ & $26.63 \pm 0.8^{\mathrm{c}}$ & $0.29 \pm 0.09^{\mathrm{c}}$ & CSH5 & $57.61 \pm 0.73^{\mathrm{c}}$ & $3.92 \pm 0.23^{\mathrm{h}}$ & $0.08 \pm 0.03^{\mathrm{d}}$ \\
\hline
\end{tabular}




\begin{tabular}{|c|c|c|c|c|c|c|c|}
\hline CSF6 & $15.26 \pm 0.6^{\mathrm{j}}$ & $0.04 \pm 0.01^{\mathrm{i}}$ & $0.07 \pm 0.02^{\mathrm{c}}$ & CSH6 & $5.18 \pm 0.43^{\mathrm{o}}$ & $0.24 \pm 0.09^{\mathrm{h}}$ & $0.75 \pm 0.06^{\mathrm{d}}$ \\
\hline CSF7 & $54.65 \pm 1.02^{\mathrm{e}}$ & $0.18 \pm 0.06^{\mathrm{i}}$ & $0.45 \pm 0.1^{\mathrm{c}}$ & CSH7 $^{\mathrm{d}}$ & $9.04 \pm 0.47^{\mathrm{m}}$ & $22.2 \pm 0.54^{\mathrm{d}}$ & $0.17 \pm 0.04^{\mathrm{d}}$ \\
\hline CSF8 & $8.25 \pm 0.66^{\mathrm{k}}$ & $0.18 \pm 0.06^{\mathrm{i}}$ & $0.86 \pm 0.12^{\mathrm{c}}$ & CSH8 & $16.34 \pm 0.6^{\mathrm{k}}$ & $2.18 \pm 0.14^{\mathrm{h}}$ & $0.2 \pm 0.07^{\mathrm{d}}$ \\
\hline CSF9 & $1.34 \pm 0.24^{\mathrm{l}}$ & $1.54 \pm 0.49^{\mathrm{i}}$ & $0.49 \pm 0.08^{\mathrm{c}}$ & CSH9 & $2.28 \pm 0.49^{\mathrm{p}}$ & $0.66 \pm 0.11^{\mathrm{h}}$ & $0.49 \pm 0.05^{\mathrm{d}}$ \\
\hline CSF10 & $2.92 \pm 0.21^{\mathrm{l}}$ & $0.19 \pm 0.02^{\mathrm{i}}$ & $0.15 \pm 0.04^{\mathrm{c}}$ & CSH10 & $20.13 \pm 0.68^{\mathrm{i}}$ & $0.18 \pm 0.05^{\mathrm{h}}$ & $0.59 \pm 0.07^{\mathrm{d}}$ \\
\hline
\end{tabular}

Table 9: Quantitative extracellular enzyme activity in the bacterial strains isolated from the GI tract of $L$. Rohita fed with SBM diet, before and after commencement of feeding trial.

\begin{tabular}{|c|c|c|c|c|c|c|c|}
\hline $\begin{array}{c}\text { Proximal } \\
\text { intestine } \\
\text { Strains }\end{array}$ & $\begin{array}{c}\text { Amylase } \\
\text { activity } \\
(\mathrm{U})^{1}\end{array}$ & $\begin{array}{c}\text { Cellulase } \\
\text { activity } \\
(\mathrm{U})^{2}\end{array}$ & $\begin{array}{c}\text { Protease } \\
\text { activity } \\
(\mathrm{U})^{3}\end{array}$ & $\begin{array}{c}\text { Distal } \\
\text { intestine } \\
\text { Strains }\end{array}$ & $\begin{array}{c}\text { Amylase } \\
\text { activity } \\
(\mathrm{U})^{1}\end{array}$ & $\begin{array}{c}\text { Cellulase } \\
\text { activity } \\
(\mathrm{U})^{2}\end{array}$ & $\begin{array}{l}\text { Protease } \\
\text { activity } \\
(\mathrm{U})^{3}\end{array}$ \\
\hline LRF1 & $0.039 \pm 0.01^{\mathrm{l}}$ & $0.54 \pm 0.19^{\mathrm{i}}$ & $1.53 \pm 0.13^{\mathrm{b}}$ & LRH1 & $12.84 \pm 0.67^{\mathrm{l}}$ & $3.25 \pm 0.45^{\mathrm{h}}$ & $2.58 \pm 0.12^{\mathrm{a}}$ \\
\hline LRF2 & $18.59 \pm 1.11^{\mathrm{i}}$ & $45.6 \pm 1.39^{\mathrm{a}}$ & $0.64 \pm 0.1^{\mathrm{c}}$ & LRH2 & $200.69 \pm 1.43^{\mathrm{a}}$ & $0.06 \pm 0.02^{\mathrm{h}}$ & $0.24 \pm 0.06^{\mathrm{d}}$ \\
\hline LRF3 & $211.76 \pm 2.2^{\mathrm{a}}$ & $0.03 \pm 0.01^{\mathrm{i}}$ & $0.33 \pm 0.08^{\mathrm{c}}$ & LRH3 & $89.04 \pm 0.8^{\mathrm{b}}$ & $41.39 \pm 1.43^{\mathrm{a}}$ & $2.73 \pm 0.15^{\mathrm{a}}$ \\
\hline LRF4 & $74.69 \pm 1.83^{\mathrm{c}}$ & $0.55 \pm 0.19^{\mathrm{i}}$ & $2.15 \pm 0.17^{\mathrm{a}}$ & LRH4 & $44.44 \pm 0.87^{\mathrm{d}}$ & $0.58 \pm 0.25^{\mathrm{h}}$ & $0.47 \pm 0.07^{\mathrm{d}}$ \\
\hline LRF5 & $1.5 \pm 0.37^{1}$ & $22.08 \pm 0.87^{\mathrm{d}}$ & $0.18 \pm 0.07^{\mathrm{c}}$ & LRH5 & $37.06 \pm 0.84^{\mathrm{e}}$ & $0.36 \pm 0.15^{\mathrm{h}}$ & $0.12 \pm 0.03^{\mathrm{d}}$ \\
\hline LRF6 & $90.66 \pm 1.31^{\mathrm{b}}$ & $13.17 \pm 0.69^{\mathrm{f}}$ & $1.78 \pm 0.14^{\mathrm{b}}$ & LRH6 & $21.89 \pm 0.77^{\mathrm{h}}$ & $7.63 \pm 0.61^{\mathrm{g}}$ & $0.76 \pm 0.12^{\mathrm{d}}$ \\
\hline LRF7 & $20.55 \pm 1.11^{\mathrm{h}}$ & $28.42 \pm 0.84^{\mathrm{b}}$ & $0.8 \pm 0.11^{\mathrm{c}}$ & LRH7 & $18.04 \pm 0.47^{\mathrm{j}}$ & $16.24 \pm 0.79^{\mathrm{c}}$ & $1.55 \pm 0.12^{\mathrm{b}}$ \\
\hline LRF8 & $2.23 \pm 0.37^{\mathrm{l}}$ & $8.36 \pm 0.57^{\mathrm{g}}$ & $0.26 \pm 0.09^{\mathrm{c}}$ & LRH8 & $30.13 \pm 0.7^{\mathrm{f}}$ & $9.27 \pm 0.61^{\mathrm{f}}$ & $0.72 \pm 0.12^{\mathrm{d}}$ \\
\hline LRF9 & $8.1 \pm 0.73^{\mathrm{k}}$ & $16.17 \pm 0.7^{\mathrm{c}}$ & $1.38 \pm 0.11^{\mathrm{b}}$ & LRH9 & $10.34 \pm 0.59^{\mathrm{m}}$ & $2.52 \pm 0.36^{\mathrm{h}}$ & $0.08 \pm 0.02^{\mathrm{d}}$ \\
\hline LRF10 & $25.35 \pm 1.06^{\mathrm{j}}$ & $2.13 \pm 0.34^{\mathrm{i}}$ & $0.72 \pm 0.08^{\mathrm{c}}$ & LRH10 & $25.46 \pm 0.82^{\mathrm{g}}$ & $23.55 \pm 0.76^{\mathrm{c}}$ & $1.18 \pm 0.11^{\mathrm{c}}$ \\
\hline
\end{tabular}

${ }^{1} \mu \mathrm{g}$ of maltose liberated $\mathrm{mL}^{-1}$ of culture filtrate.

${ }^{2} \mu \mathrm{g}$ of glucose liberated $\mathrm{mL}^{-1}$ of culture filtrate.

${ }^{3} \mu \mathrm{g}$ of tyrosine liberated $\mathrm{mL}^{-1}$ of culture filtrate.

Data are mean of 3 determinations \pm standard deviation. Means in the same column with same superscripts are not significantly different $(P<0.05)$.

\section{DISCUSSION}

Modulation of the fish gut microbiota by diets has been demonstrated in several studies $[5,13,14,15,16,17,18]$. The present study has confirmed that gut microbiota of fish are sensitive to dietary changes. Furthermore, the effect of dietary components such as soybean meal on the gut microbiota is important to investigate as the GI tract is one of the major routs of infection in fish $[13,16]$.

Soybean meal (SBM) is a valuable protein source of plant origin with a generally good nutritional balance for aqua feeds [17]. However, the presence of anti-nutrients leads to reduced growth and feed utilization. Most anti-nutrients can be reduced by physical, chemical or biochemical treatments, such as inactivation of trypsin inhibitor by heat, reduction of carbohydrate content by methanol extraction or hydrolysis of phytic acid by phytase. The intestinal microbiota of fish is still poorly known. Replacement of fishmeal with SBM (at 30\% inclusion) had no significant effect on the levels of total aerobic bacteria, total anaerobic bacteria, presumptive E. coli, Aeromonas, Bi-fidobacterium or Clostridium in the intestine of silver crucian carp (Carassius auratus gihelio x Cyprinus carpio) [19]. And also Merrifield et al. (2009) [20] reported that dietary SBM does not significantly alter viable microbial numbers in the intestinal tract of rainbow trout, Oncorhynchus mykiss and also these results together with those found by [21] suggest that quantitative changes of total viable populations of gut microbiota of salmonids may be less influenced by SBM than in other species, such as Atlantic cod, Gadus morhua [16] where it often resulted in higher populations. On the other hand, Heikkinen et al. (2006) [17] and Bakke-McKellep et al. (2007) [22] observed changes in total microbial populations in rainbow trout and Atlantic salmon, respectively. Heikkinen et al. (2006) [17] demonstrated that SBM-fed rainbow trout displayed an initial increase of viable intestinal microbes, but after 8 weeks feeding these levels dropped below that of the control-fed fish. Bakke-McKellep et al. (2007) [22] observed significant increases of total viable count of autochthonous populations in both the mid and distal intestine of SBM-fed Atlantic salmon compared with the control group. Allochthonous populations in the distal intestine were also significantly higher in the SBMfed fish. In the present study, also the bacterial population increased in the gut of L. rohita fed SBM based diet in comparison 
to the FM fed groups. There are reports of isolation of microbes on selective media [23, 24]. Ringø et al. (1995) [25] suggested that several nutrient media should be used to achieve a better understanding of the microbiota of the GI tract of fish. In this study, proteolytic, amylolytic and cellulolytic bacteria were isolated on agar media supplemented with peptone-gelatin, starch and carboxymethylcellulose (CMC), respectively. In this investigation amylase and cellulase producing bacterial population increased in PI of SBM fed fish than FM fed fish gut bacterial population. Protease producing bacterial population was also increased in the SBM fed group.

The gut microbiota is important in fish health $[26,27]$ and it has been suggested that the autochthonous gut microbiota could inhibit colonization of pathogenic bacteria by mechanisms including space occupation, competition of nutrients, blocking receptors on mucosal surface and production of antagonistic compounds [e.g. 14, 16, 28]. Activity of carbohydrases in general and of amylase in particular, differs from species to species, and appears to be related to their feeding habits. In a recent study, [29] evaluated the dietary effect of different carbohydrate sources, broken rice, dextrin, cassava bagasse, ground corn and wheat bran, on total heterotrophic cultivable autochthonous and amylolytic gut bacteria in DI of tilapia and jundia (Rhamdia quelen). Das and Tripathi (1991) [7] reported high amylase activity in the GI tract of grass carp, Ctenopharyngodon idella, which appeared to be the result of its omnivorous feeding habit. Mondal et al. (2008b) [30] also detected a considerable population of amylolytic bacteria in the fish species with herbivorous and omnivorous feeding habits. Askarian et al. (2013) [5] reported that the diversity of most promising enzyme-producing bacteria isolated from the GI tract of Atlantic cod seems to be influenced by the feeding regimes. The most promising enzyme-producing bacteria isolated from FM fed fish. This isolate exhibited high protease and cellulase activities but moderate chitinase and amylase activities. The most promising enzyme-producing gut bacteria isolated from SBM group was similar to Brochothrix sp. and was isolated from the foregut. The Brochothrix sp. isolated from the SBM treatment was the only isolate of all isolates investigated with high lipase activity. Brochothrix sp., Psychrobacter sp., Carnobacterium sp. and Staphylococcus equorum displayed high protease and to some extent phytase activities. Surprisingly, no amylase activity was detected in the most promising enzymeproducing bacteria isolated from the SBM treatment.

Till date, most of the investigations were done in Atlantic cod (Salmo salar) and some carp species, and the dominant bacteria colonizing the GI tract have been identified as Aeromonas, Pseudomonas, Enterobacteriaceae, Micrococcus, Acinetobacter, Clostridium, Fusarium, Bacteroides, Flavobacterium, Plesiomonas and Bacillus [4]. In the present investigation, attention has been focused on the aerobic GI tract autochthonous bacteria enzyme producing ability of Indian major carp Labeo rohita fed with SBM. In this study cellulase activity increased dramatically in some SBM fish gut bacterial strains compared with FM fed fish gut bacteria. Amylase producing activity does not increased significantly in SBM fish gut bacterial strains than the FM fed fish gut bacterial strains. Whereas protease producing capability increased in SBM fed fish gut bacteria.

\section{CONCLUSION}

The present investigation indicates that SBM can influence the autochthonous enzyme-producing microbial community in the GI tract of fish. Populations of cultivable enzyme-producing bacteria increased in the GI tract of fish fed experimental diets incorporated with SBM. This investigation also helps to known that in SBM fed group, cellulase and protease activities increased in some bacterial strains, whereas amylase activity did not increase significantly. Further investigations are necessary to establish the detailed mechanisms that govern the dynamic microbial community of gut and their effects on each other as well as on the host at the molecular level.

\section{REFERENCES}

[1] D.A. Higgs, B.S. Dosanjh, A.F. Prendergast, R.M. Beams, R.W. Hardy, W. Riley, G. Deacon, "Nutrition and Utilization Technology in Aquaculture", Champaign II. Chapman and Hall Company, New York, USA, pp. 130-156, 1995.

[2] A.G.J. Tacon, "Feed ingredients for warmwater fish, fish meal and other processed feedstuffs", FAO Fisheries Circular (FAO). no. 856, 1993.

[3] T O'keefe, "Plant protein ingredients for aquaculture feeds: Use considerations and quality standards", Aquaculture Seminars, $24-28$ July, 2003. Mymensingh-Khulna- Dhaka, Bangladesh, 14 p. 2003.

[4] A.K. Ray, K. Ghosh, E. Ringø, "Enzyme-producing bacteria isolated from fish gut: A review", Aquaculture Nutrition 18, 465-492, 2012a.

[5] F. Askarian, S. Sperstad, D.L. Merrifield, A.K. Ray, E. Ringø, "The effect of different feeding regimes on enzyme activity of Atlantic cod (Gadus morhua L.) gut microbiota" Aquaculture Research, 44, 841-846, 2013.

[6] E. Ring $\varnothing$, E. Strøm, "Microflora of Arctic charr, Salvelinus alpinus (L.): gastrointestinal microflora of free-living fish and effect of diet and salinity on intestinal microflora", Aquaculture Research, 25(6), 623-629, 1994.

[7] K.M. Das, S.D. Tripathi, "Studies on the digestive enzymes of grass carp, Ctenopharyngodon idella (Val.)", Aquaculture, 92, $21-32,1991$.

[8] G. Banerjee, A.K. Ray, F. Askarian, E. Ringø, "Characterisation and identification of enzyme-producing autochthonous bacteria from the gastrointestinal tract of two Indian air-breathing fish”, Beneficial Microbes, 4, 277-284, 2013. 
[9] O.H. Lowry, N.J. Rosebrough, A.L. Farr, R.J. Randall, "Protein measurement with the folin phenol reagent”, Journal of biological chemistry, 193, 265-275, 1951.

[10] P. Bernfeld, “Amylase [alpha] and [beta]. In: Kolowick SP, Kaplan NO (Eds.) Methods of enzymology”, Academic Press, New York, NY, USA, pp. 149-150, 1955.

[11] D.A. Denison, R.D. Koehn, "Cellulase activity of Poronia Oedipus", Mycologia, 69, 592-601, 1977.

[12] H.E. Walter, "Methods of enzymatic analysis", Verlag Chemie, Weinheim, Germany, 1984.

[13] T.H. Birkbeck, E. Ringø, "Pathogenesis and the gastrointestinal tract of growing fish", In: W Holzapfel, P.Naughton, (Eds.), Microbial Ecol Growing Ani, Elsevier, Edinburgh, UK, pp. 208-234, 2005.

[14] E. Ring $\varnothing$, U Schillinger, W. Holzapfel, "Antibacterial abilities of lactic acid bacteria isolated from aquatic animals and the use of lactic acid bacteria in aquaculture", In: Holzapfel W, Naughton P (Eds.) Microbial Ecology in Growing Animals, Elsevier, Edinburgh, pp. 418-453, UK 2005.

[15] K. Korsnes, O. Nicolaisen, C.K. Skår, A.H. Nerland, Ø. "Bergh, Bacteria in the gut of juvenile cod Gadus morhua fed live feed enriched with four different commercial diets", ICES Journal of Marine Science: Journal du Conseil, 63(2), 296-301, 2006.

[16] E. Ring $\varnothing$, S. Sperstad, R. Myklebust, S. Refstie, Å. Krogdahl, 'Characterisation of the microbiota associated with intestine of Atlantic cod (Gadus morhua L.). The effect of fish meal, standard soybean meal and bioprocessed soybean meal', Aquaculture, 261, 829-841, 2006b.

[17] J. Heikkinen, J. Vielma, O. Kemilainen, M. Tiirola, P. Eskelinen, T. Kiuru, D. Navia- Paldanius, A. von, "Wright Effects of soybean meal based diet on growth performance, gut histopathology and intestinal microbiota of juvenile rainbow trout (Oncorhynchus mykiss)", Aquaculture, 261, 259-268, 2006

[18] S.K. Nayak, "Probiotics and immunity: a fish perspective" Fish and Shellfish Immunology, 29, 2-14, $2010 \mathrm{~b}$.

[19] C.F. Cai, W.J. Wang, T.T. Ye, A. Krogdahl, Y.L. Wang, Y.M. Xia, C.G. Yang, "Effect of soybean meal, raffinose and stachyose on the growth, body composition, intestinal morphology and intestinal microflora of juvenile allgynogenetic silver crucian carp (Carrassius auratus gibelio 9 Cyprinus carpio ${ }^{\lambda}$ )", Aquaculture Ressearch, 41,128-138, 2012.

[20] D.L. Merrifield, A. Dimitroglou, G. Bradley, R.T.M. Baker, S.J. Davies, "Soybean meal alters autochthonous microbial populations, microvilli morphology and compromises intestinal enterocyte integrity of rainbow trout (Oncorhynchus mykiss Walbaum)”, Journal of Fish Diseases, 32, 755-766, 2009.

[21] E. Ringø, S. Sperstad, O.F. Kraugerud, Å. Krogdahl, "Use of 16S rRNA gene sequencing analysis to characterize culturable intestinal bacteria in Atlantic salmon (Salmo salar) fed diets with cellulose or non-starch polysaccharides from soy", Aquaculture Research, 39 (10),1087-1100, 2008.

[22] A.M. Bakke-McKellep, M.H. Penn, P. Mora Salas, S. Refstie, S. Sperstad, T. Landsverk, E. Ring $\varnothing$, Å. Krogdahl, "Effects of dietary soyabean meal, inulin and oxytetracycline on intestinal microbiota and epithelial cell stress, apoptosis and proliferation in the teleost Atlantic salmon (Salmo salar L.)", British Journal of Nutrition, 97, 699-713, 2007.

[23] C. Jeppesen, "Media for Aeromonas spp., Plesiomonas shigelloides and Pseudomonas spp. from food and environment”, International journal of food microbiology, 26, 25-41, 1995.

[24] T.J. Donovan, P. van Netten, "Culture media for the isolation and enumeration of pathogenic Vibrio species in foods and environmental samples", In Progress in industrial microbiology, 34, 203-217, Elsevier, 1995.

[25] E. Ringø, E, Strøm, J.L. Tabachek, "Intestinal microflora of salmonids: a review", Aquaculture Research, 26, 773-789, 1995.

[26] D.L. Merrifield, G. Bradley, R.T. Baker, S.J. Davies, "Probiotic applications for rainbow trout (Oncorhynchus mykiss Walbaum) II. Effects on growth performance, feed utilization, intestinal microbiota and related health criteria post antibiotic treatment", Aquaculture Nutrition, 16(5), 496-503, 2010b.

[27] S.K. Nayak, "Role of gastrointestinal microbiota in fish", Aquaculture Research, 41, 1553-1726, 2010a.

[28] C.M. Caipang, M.F. Brinchmann, V. Kiron, "Antagonistic activity of bacterial isolates from intestinal microbiota of Atlantic cod, Gadus morhua, and an investigation of their immunomodulatory capabilities" Aquaculture Research, 41(2), 249-256, 2010.

[29] F.S. Pedrotti, S. Davies, D.L. Merrifield, M.R.F. Marques, A.P.M Fraga, J.L.P. Mouri no, D.M. Fracalossi, "The autochthonous microbiota of the freshwater omnivores jundi_a (Rhamdia quelen) and tilapia (Oreochromis niloticus) and the effect of dietary carbohydrates", Aquaculture Research, 46, 472-481. 2015.

[30] S. Mondal, T. Roy, S.K. Sen, A.K. Ray, "Distribution of enzyme producing bacteria in the digestive tracts of some freshwater fish", Acta Ichthyologica et Piscatoria, 38, 1-8, $2008 \mathrm{~b}$. 